by the Southwest Center for Advanced Studies, the University of Texas and the Yeshiva University, was held at Dallas, Texas, during December $16-18,1963$. The symposium was notable for producing many interesting and exciting ideas on the implosive final stage of 'stars' of large mass ( $\sim 10^{8}$ solar masses). The purpose of the symposium was to see if any progress could be made towards understanding the strange radio sources identified with optical objects of almost stellar appearance. Theoretical and observational investigations were reported and will be published as a book by the University of Chicago Press.

\section{Electrochemical Research on Aqueous Systems at Elevated Temperatures and Pressures}

AN informal seminar on "Electrochemical Research on Aqueous Systems at Elevated Temperatures and Pressures" was held at the Central Electricity Research Laboratories, Leatherhead, on December 13. The meeting was organized by the Physical Chemistry Section at the Research Laboratories as a result of a research programme on the properties of supercritical water and boiler corrosion. Prof. W. F. K. Wynne-Jones (University of Newcastle upon Tyne) acted as chairman, and Mr. J. M. Ward welcomed the visitors on behalf of the Central Electricity Research Laboratories. Prof. E. U. Franck (Institute for Physical Chemistry and Electrochemistry, Karlsruh $\theta$ ) opened the seminar with the lecture "Research on Aqueous Systems at Elevated Temperatures and Pressures at the Institute for Physical Chemistry and Electrochemistry, Karlsruhe". In it he deseribed the pressure equipment and conductance cells that had been used in the measurement of the conductivity of dilute aqueous solutions at temperatures and pressures up to $800^{\circ} \mathrm{C}$ and $4,000 \mathrm{~kg} / \mathrm{cm}^{2}$, respectively. He also described work on decomposition voltages and the visible and ultra-violet spectra of solutions. Prof. Wynne-Jones then gave an address on "The Conductivity of Salt Solutions at Temperatures up to $200^{\circ} \mathrm{C}$ and Pressures up to 2,000 $\mathrm{kg} / \mathrm{cm}^{2}$ ". In it he considered the effect of the change in ionic radii on conductivity. In the afternoon, Prof. G. J. Hills (University of Southampton) spoke on "Theoretical Developments in Aqueous Electrochemistry". He considered the application to conductivity and ion mobilities of the transition state theory of Eyring and described the work earried out at the University of Southampton on conductivity and interfacial volumes. The meeting was then opened to discussion for the remainder of the afternoon. Great interest was expressed in new unpublished data, presented by Dr. K. E. Bett (Imperial College of Science and Technology), on the viscosity of water from $10^{\circ}$ to $75^{\circ} \mathrm{C}$ and at pressures between 1,000 and 9,000 $\mathrm{kg} / \mathrm{cm}^{2}$. Prof. E. U. Franck gave a short account of the use of computers to calculate the ionic strength of solutions at elevated temperature and pressure. The meeting was then closed, and Mr. Ward, on behalf of the Resoarch Laboratories, thanked the visitors for attending.

\section{Books for Chemical Engineers}

THE Institution of Chemical Engineers (16 Belgrave Square, London, S.W.1) has recently published a pamphlet, Books for Chemical Engineers. The books referred to are mainly the proceedings (papers and discussion) of various symposia which have been organized by the Institution in recent years. The topics covered are: the handling of solids; the interaction between fluids and particles; process optimization; catalysis in practice; chemical process hazards; distillation; instrumentation and computation in process development and plant design; the scaling-up of chemical plant and processes; the organization of chemical engineering processes; particle size analysis. Forthcoming publications will deal with: civil and structural engineering considerations in chemical plant design; the less common means of separation; chemical engineering in the metallurgical industries.
The pamphlet gives the contents, price and date of each publication. It is noteworthy that it proved possible to publish the proceedings of a symposium held in June 1963 in the same year.

\section{Research and the Paper Industry}

What We are Doing is a publication issued four times a year by the British Paper and Board Industry Research Association, of St. Winifred's Laboratories, Welcomes Road, Kenley, Surrey. It is compiled by the Association's Mill Enquiry and Liaison Service, and it is composed of two parts, the larger of which is intended to implement its title. The smaller is a confidential section issued to members of the Association only; it is excluded from issues sent to non-members such as the copy under review, which therefore may justifiably be regarded mainly as a publicity effort. This being the case, it is natural to find that it deals appropriately, if rather superficially, with the general activities of the Association, and in particular with such matters as the information service, book reviews, and a report on baling wires which evidently is regarded as suitable for release to non-members. The interesting article on the information department contains an outline of subject classification in terms of the decimal system of reference. Several pages of abstracts from the foreign literature complete this issue. It will be appreciated that a publication shorn of its most valuable scientific contributions will be only of passing interest to readers of Nature who are not members of the Association. This should not be allowed to load to an underestimate of the value of the research work being carried out by the Association. 'This is concerned primarily with the fundamental properties of paper and its fibres and their bearing on the processes of the industry. It is less concerned with the raw materials used or with the uses of paper, the latter being rather the province of the Printing, Packaging and Allied Trades Research Association. The present publication serves a useful purpose in directing attention to the existence of the Association (which has grades of membership covering a wide range of allied trades), and the crumbs of information it supplies may perhaps whet the appetite of nonmembers for some more solid fare.

\section{The Royal Society and Nuffield Commonwealth Bur- saries Scheme}

AwArDs under the Royal Society and Nuffield Foundation Commonwealth Bursaries Scheme have been made as follows: Prof. H. N. Barber, professor of botany, University of New South Wales, to enable him to study botanical physics at Rothamsted Experimental Station and elsewhere in the United Kingdom; Prof. B. S. Basak, professor of physics, Presidency College, Calcutta, to enable him to learn modern techniques in crystal structure determination, with special reference to the application of computers to crystallographic calculations, at Oxford; Dr. M. J. P. Canny, university lecturer in botany, Cambridge, to enable him to visit Makerere College, Uganda, in order to measure the apparent diffusion constant of sucrose in the translocation system of cotton, and to assist in setting up a radioactivity unit there; Dr. Chew Wee-Lek, Botanic Gardens, Singapore, to enable him to study the generic limits of the Urticaceae in preparation for a taxonomic revision of the Malaysian species, at Cambridge; Dr. J. B. Falls, associate professor of zoology, University of Toronto, to enable him to visit Canberra in order to study acoustical behaviour of Australian magpies and to gain a knowledge of ecological conditions and research in A.ustralia; L. V. Hawkins, senior lecturer in geophysics, University of New South Wales, to enable him to take part in research at the Imperial College of Science and Technology in the fields of seismology and the elastic behaviour of rocks; A. C. Jenkins, senior lecturer (analyst) in agricultural chemistry, University of Adelaide, 